\title{
БИОХИМИЧЕСКИЕ И ИММУНОЛОГИЧЕСКИЕ ПОКАЗАТЕЛИ ПРИ НЕБЛАГОПРИЯТНОМ ТЕЧЕНИИ ТУБЕРКУЛЕЗА ЛЕГКИХ
}

\author{
Ф. К. Ташпулатова, М. Ш. Босимов, К. К. Бобониязов \\ Ташкентский педиатрический медицинский институт \\ Узбекистан, 100140 г. Ташкент, ул. Богишамол, 223 \\ 凶 Ташпулатова Фатима Кудратовна - fatima2263@mail.ru
}

Обследовано 70 больных с инфильтративным туберкулезом легких. По течению прочесса выделяли 3 группы больных: с тяжелым течением, торпидным, благоприятным течением процесса и с хроническим течением туберкулеза. Установлено, что среди изученных биохимических предикторов, наибольшие изменения претерпевает активность фермента пероксидазы: при инволютивном течении процесса, активность пероксидазы в крови увеличивается до $265 \pm 8,54$ мкмоль/л, при прогрессировании туберкулеза активность фермента падает до 226 6,4 мкмоль/л. Изучено взаимосвязь процессов перекисного окисления и нарушения отдельных звеньев иммунитета у больных туберкулезом легких. Доказано, что в зависимости от типа течения туберкулеза легких изменяются окислительные процессы.

Ключевые слова: туберкулез легких, биохимические показатели, иммунологические показатели, хронизация.

\section{BIOCHEMICAL AND IMMUNOLOGICAL PARAMETERS WITH UNFAVORABLE COURSE OF PULMONARY TUBERCULOSIS}

\author{
F. K. Tashputalova, M. Sh. Bosimov, K. K. Boboniyazov \\ Tashkent Pediatric Medical Institute \\ 223 Bogishamol St., 100140 Taskkent, Uzbekistan \\ \ashpulatova Fatima - fatima2263@mail.ru \\ It was researched 70 patient with infiltrative tuberculosis of lungs. By during process divided to 3 groups: severe, torpid and \\ advantageous cause and with chronic process of tuberculosis. It was determined that among biochemical research predictors \\ most of all changes was enzyme peroxides, advantageous process activity of enzyme peroxides in blood was increased until \\ $265 \pm 8,54 \mu \mathrm{mol} / \mathrm{l}$, in progression of TB activity of enzyme peroxides decrease until $226 \pm 6,4 \mu \mathrm{mol} / \mathrm{l}$. Researched interrelation of \\ processes peroxide oxidization and disorders of separate elements of immunity in patients with tuberculosis of lung. Evidenced, \\ the depending on from type of flowing of lungs tuberculosis changes the oxidization processes.
}

Keywords: tuberculous of lungs, biochemical indices, immunological indices, chronization.

Введение: В условиях напряженной эпидемиологической ситуации по туберкулезу во всем мире и в Центрально-Азиатском регионе в частности нарастает частота неблагоприятного течения - переход в хронические формы туберкулеза [7, с. 66], которые трудно поддаются лечению. Одной из причин, способствующих развитию хронических форм заболевания, является недостаточная эффективность лечения больных туберкулезом, особенно с наличием распада легочной ткани и бактериовыделением, которые представляют главную эпидемиологическую опасность для окружающих.

Ежегодно у 15-20\% вновь выявленных больных деструктивным туберкулезом легких, процесс переходит в хроническую форму, несмотря на проводимые лечебные мероприятия [8, с. 25]. В связи с этим пристальный интерес вызывают вопросы изучения различных аспектов патогенеза туберкулезного воспаления.

Наиболее перспективным в этом направлении является изучение биохимических и иммунологических основ воспалительного процесса, особенно процесса хронизации туберкулеза [3, с. 30].

Нами была изучена взаимосвязь процессов перекисного окисления липидов и нарушения отдельных звеньев иммунологического статуса до и после лечения при острых и хронических формах туберкулезе легких. В качестве показателей антиоксидантной системы были изучены ряд ферментов крови: каталаза, пероксидаза, церулоплазмин, содержание продуктов перекисного окисления липидов.

В результате проведенных исследований установлена взаимосвязь между уровнем перекисного окисления липидов и активностью ферментов антиоксидантной защиты (медьоксидаза, пироксидаза) до и под влиянием разного лечения. Реактивность клетки тесно связана с состоянием клеточных мембран и состоянием окислительно-восстановительных процессов самой клетки [4, с. 44; 2, с. 186]. Ряд сообщений свидетельствует о том, что нарушение перекисного окисления липидов изменяет структуру мембран и угнетает активность клетки с одной стороны, а с другой связана с ферментом антиоксидантной защиты [5, с. 40; 9, с. 101]. Хронизация процесса связана с нарушениями в клетках иммунной системы.

Цель исследования: изучить состояние биохимических и иммунологических показателей пониженной сопротивляемости у больных инфильтративным туберкулезом легких и на этой основе выделить биохимические и иммунологические параметры хронизации туберкулеза.

материалы и методы исследования. Для достижения поставленной цели были обследованы 70 больных с инфильтративным туберкулезом легких в возрасте от 20 до 55 лет. Всем больным проводили комплексное клинико-лабораторное, иммунологическое обследования. Среди клинических симптомов в динамике определяли следующие симптомы: температуру тела и вес больного, наличие и характер кашля, слабость, кровохарканье, наличие выра- 
Показатели пол и антиоксидантной защиты у больных с туберкулезом легких с разным течением

\begin{tabular}{|c|c|c|c|c|c|}
\hline Группа & $\begin{array}{c}\text { Церулоплазмин } \\
\text { ЦП }\end{array}$ & $\begin{array}{c}\text { Коньюгаты } \\
\text { ДК }\end{array}$ & $\begin{array}{c}K=ц \Pi \\
д K\end{array}$ & Пероксидаза & Каталаза \\
\hline $\begin{array}{l}1 \text { группа } \\
\text { прогрессирующее течение }\end{array}$ & $\begin{array}{c}26,9 \pm 2,3 \\
p<0,01\end{array}$ & $\begin{array}{l}10,9 \pm 0,61 \\
p<0,001\end{array}$ & $\begin{array}{l}2,5 \pm 0,22 \\
p<0,001\end{array}$ & $\begin{array}{l}226,3 \pm 6,4 \\
p<0,001\end{array}$ & $\begin{array}{l}44,3 \pm 5,49 \\
p<0,001\end{array}$ \\
\hline $\begin{array}{l}2 \text { группа } \\
\text { инволютивное течение }\end{array}$ & $\begin{array}{l}27,8 \pm 1,88 \\
p<0,001\end{array}$ & $\begin{array}{c}11,7 \pm 0,68 \\
p<0,001\end{array}$ & $\begin{array}{l}2,4 \pm 0,14 \\
p<0,001\end{array}$ & $\begin{array}{l}265 \pm 8,54 \\
p<0,001\end{array}$ & $\begin{array}{c}59,9 \pm 8,67 \\
p<0,1\end{array}$ \\
\hline $\begin{array}{l}3 \text { группа } \\
\text { хроническое течение }\end{array}$ & $\begin{array}{l}24,0 \pm 2,09 \\
p<0,001\end{array}$ & $\begin{array}{l}10,9 \pm 0,64 \\
p<0,001\end{array}$ & $\begin{array}{l}2,3 \pm 0,18 \\
p<0,001\end{array}$ & $\begin{array}{c}246,8 \pm 7,47 \\
p<0,001\end{array}$ & $\begin{array}{l}50,7 \pm 7,08 \\
\mathrm{p}<0,001\end{array}$ \\
\hline Здоровые лица & $\begin{array}{l}20,5 \pm 0,44 \\
\text { ед }\end{array}$ & $\begin{array}{c}4,8 \pm 0,51 \\
\text { мкмоль\л }\end{array}$ & $4,2 \pm 0,08$ & $\begin{array}{l}247,9 \pm 5,7 \\
\text { мкмоль \л }\end{array}$ & $\begin{array}{l}16,8 \pm 3,16 \\
\text { мкмоль\л }\end{array}$ \\
\hline
\end{tabular}

женной одышки. Среди биохимических показателей определяли перкисное окисление липидов-пОЛ по Арчаковой А.И. (1972), активность церулоплазмина в сыворотке крови по Ravin (1976), активность фермента каталазы по Коралюк М.А. (1988), пероксидазы по Поповой Т.С. (1971) [1, с. 120]. Среди иммунологических показателей определяли Е-РОК, ЕАС-РОК, РБТЛ с ППД и состояние фагоцитоза, динамику морфологических изменений лимфоцитов крови [6, с. 380].

Статистическую обработку результатов исследования проводили с применением современных вычислительных систем типа IBM/PQ последнего поколения с помощью пакета стандартных программ Exel. Все значения в таблицах представлены в виде средней арифметической величины вариационного ряда + ошибка средней величины (M $\pm \mathrm{m})$. Для сравнения средних значений между группами применялись критерий t Стьюдента.

Результаты исследований: По течению процесса выделяли 3 группы больных: 1 группа состояла из 30 пациентов с тяжелым, остро прогрессирующим течением процесса. В эту группу вошли больные с казеозной пневмонией, с острым началом и прогрессирующим клиническим течением заболевания; 2 группа состояла из 25 больных с ограниченными формами, маловыраженной симптоматикой и торпидным, благоприятным течением процесса; и 3 группа больных состояла из 15 человек с хроническим течением туберкулеза с фиброзно-кавернозным процессом.

Было установлено, что среди исследованных биохимических предикторов, наибольшие изменения претерпевает активность фермента пероксидаза, причем, при инволютивном течении процесса, активность пероксидазы в крови увеличивается до $265 \pm 8,54$ мкмоль/л (при норме $247 \pm 5,7)$, а при прогрессировании туберкулеза активность фермента наоборот, падает до 226士6,4 мкмоль/л. Фермент каталаза в сыворотке крови также изменяется: при инво-

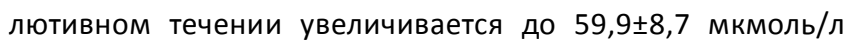
(при норме 16,8ะ6,16), при прогрессировании туберкулеза

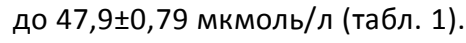

Установлено, что при инфильтративном туберкулезе происходят так же значительные изменения в иммунологических показателях: наибольшая корреляция отмечена между изменениями активности пероксидазы и активности фагоцитоза. Наибольшие изменения со стороны клеточного, гуморального и специфического иммунитета, а также неспецифической резистентности наблюдались при инволютивном течении туберкулеза: Е- РОК 49,8 $2,1 \%$, ЕАС РОК

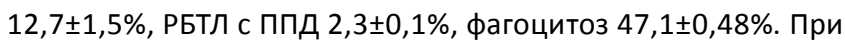
прогрессировании туберкулеза также выявлены выраженные изменения (Е- РОК 50,3 $\pm 0,9 \%$, ЕАС РОК $13,1 \pm 1,7 \%$, РБТЛ

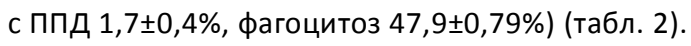

Обсуждение: При сопоставлении характера изменений в активности ферментов и показателей иммунитета сразу обращает на себя внимание противоположный характер этих изменений. При этом следует учитывать, что указанные изменения коррелируют между собой не в полной мере. Следовательно, при хронизации нарушения в иммунном статусе менее выражены, чем в окислительных процессах. Их роль в патогенезе хронизации процесса туберкулеза выражена меньше и имеет разное влияние на весь процесс хронизации. Имеющиеся литературные данные показывают, что при хроническом процессе именно окислительные процессы снижаются в большей степени, чем другие обменные процессы (Мишин В.Ю., 1992; Каминская Г.О, и соавт., 2006; Есимова И.Е., 2007). Степень их выраженности определяется вариантом (лекарственно-чувствительный или лекарственноустойчивый) и клинической формой (инфильтративный, диссеминированный, фиброзно-кавернозный) заболевания. Полученные данные указывают о необходимости включения в стандарты лечения туберкулеза дифференцированной тактики патогенетической терапии направленной на устранения дисбаланса между биохимическими и иммунологическими показателями

Таблица 2

Иммунологические показатели у больных с туберкулезом легких с разным течением

\begin{tabular}{|c|c|c|c|c|}
\hline Группа & Е-РОК \% & ЕАС-РОК \% & РБтл с пПд & Фагоцитоз \\
\hline $\begin{array}{l}1 \text { группа } \\
\text { прогрессирующее течение }\end{array}$ & $\begin{array}{l}50,3 \pm 0,9 \\
p<0,001\end{array}$ & $\begin{array}{l}13,1 \pm 1,7 \\
p<0,05\end{array}$ & $\begin{array}{l}1,7 \pm 0,4 \\
P>0,5\end{array}$ & $\begin{array}{c}47,9 \pm 0,79 \\
p<0,001\end{array}$ \\
\hline $\begin{array}{l}2 \text { группа } \\
\text { инволютивное течение }\end{array}$ & $\begin{array}{l}49,8 \pm 2,1 \\
p<0,001\end{array}$ & $\begin{array}{l}12,7 \pm 1,5 \\
p<0,001\end{array}$ & $\begin{array}{l}2,3 \pm 0,1 \\
P<0,02\end{array}$ & $\begin{array}{c}47,1 \pm 0,48 \\
p \leq 0,001\end{array}$ \\
\hline $\begin{array}{l}3 \text { группа } \\
\text { хроническое течение }\end{array}$ & $\begin{array}{l}49,8 \pm 2,1 \\
p<0,001\end{array}$ & $\begin{array}{l}12,7 \pm 1,5 \\
p<0,001\end{array}$ & $\begin{array}{l}2,3 \pm 0,1 \\
p<0,02\end{array}$ & $\begin{array}{c}47,1 \pm 0,48 \\
p<0,001\end{array}$ \\
\hline Здоровые лица & $64,4 \pm 1,6 \%$ & $16,4 \pm 0,6 \%$ & $1,3 \pm 0,4 \%$ & $58,1 \pm 1,1 \%$ \\
\hline
\end{tabular}


Выводы: у больных с инфильтративным туберкулезом легких наиболее часто и наиболее резко изменяется активность пероксидазы, каталазы и перекисное окисление липидов. Выявленные изменения в биохимических и иммунологических показателях у больных с острым, неблагоприятным течением с переходом в хронические формы указывают о необходимости проведения патогенетической коррекции в схемы терапии.

\section{ЛИТЕРАТУРА}

1. Арипов А.Н., Фесенко Л.М. Клиническая биохимия. Методы. Т.: Абу Али Ибн Сино. 2007. 271 с.

2. Есимова И.Е. Состояние липидной фазы мембраны мононуклеарных клеток крови при туберкулезе легких. Дисс. ... канд. мед. наук, Томск. 2007. 214 с.

3. Каминская Г.О., Абдуллаев Р.Ю. Изменения уровней оксида азота в мононуклеарах и нейтрофилах крови у больных с разным течением туберкулеза легких // Проблемы туберкулеза и болезней легких. 2004. № 8. С. 41-45

4. Махаматов К.М., Рахимов А.Х. Клинико-патогенетическая роль нарушений процессов перекисного окисления липидов и антиоксидантной функции при внутригрудном туберкулезе у детей // Материалы тезисов IV Съезда фтизиатров Казахстана. 1992. АлмаАта. С. 43-44

5. Мишин В.Ю., Круглова Е.Г. Ферменты лимфоцитов, активность процессов перекисного окисления липидов и антиоксидантной защиты у больных туберкулезом легких // Проблемы туберкуле3а. 1992. № 9. С. 38-41

6. Походзей И.В. Иммунологические методы исследования // Руководство по болезням органов дыхания. М.: Медицина. 1989. T. 1. C. $379-388$

7. Тилляшайхов М.Н., Алимов С.В., Усманова Ш.Ш., Сотволдиев Н.А. Динамика основных показателей туберкулеза легких в Республике Узбекистан // Материалы VIII Съезда фтизиатров и пульмонологов Узбекистана. 2015. Ташкент. С. 66

8. Туберкулез органов дыхания: Руководство для врачей // Под ред. А.Г. Хоменко. М.: Медицина. 1983. 576 с.

9. Черник Р.Б., Ахатов И.М., Абдуллаева В.А. Оценка тяжести течения бронхиальной астмы по соотношению активности перекисного окисления липидов и церулоплазмина // Актуальные вопросы фтизиатрии и пульмонологии в Узбекистане. 2001. С. 99-101

Поступила в редакцию 23.12.2016 